\author{
Zdzisław Wtodarczyk \\ Wieluńskie Towarzystwo Naukowe \\ wtn.wielun@wp.pl
}

\title{
Szkoła elementarna w Załęczu Wielkim (pow. wieluński) 1804-1859
}

Leżąca w południowo-wschodniej części powiatu wieluńskiego wieś Załęcze Wielkie poszczycić się może wielowiekową przeszłością ${ }^{1}$. Przed rozbiorami stanowiła część składową klucza kamionkowskiego kapituły arcybiskupstwa gnieźnieńskiego. Po przejściu pod panowanie Hohenzollernów (1793) znalazła się w obrębie tzw. Prus Południowych (Südpreussen). Władcy pozostawili początkowo posiadłości kościelne w rękach dawnych właścicieli. Jednak już po powstaniu kościuszkowskim zdecydowano się na ich konfiskatę. Motywem podjęcia tego radykalnego kroku były: postawa kleru podczas insurekcji, co uznano za złamanie homagium złożonego w Poznaniu (1793) królowi pruskiemu, jak i mniejszy niż sądzono wpływ duchowieństwa na umysły wiernych. Poniekąd wymówką usprawiedliwiającą wywłaszczenie były niegospodarność ich dotychczasowych posiadaczy oraz charakter zajęć nie licujący z powagą stanu duchownego.

1 O produkcji rolnej w Załęczu Wielkim pisali m.in.: J. Topolski, Rozwój latyfundium arcybiskupstwa gnieźnieńskiego od XVI do XVIII wieku, Poznań 1955; tenże, Położenie i walka klasowa chłopów w XVIII w. $w$ dobrach arcybiskupstwa gnieźnieńskiego, Poznań 1956; tenże, Gospodarstwo wiejskie w dobrach arcybiskupstwa gnieźnieńskiego od XVI do XVIII wieku, Poznań 1958; W. Szczygielski, Produkcja rolnicza gospodarstwa folwarcznego w Wieluńskiem od XVI do XVIII wieku, Łódź 1963, passim. Wieś, jej przeszłość kulturowa, stanowiły przedmiot zainteresowania etnografów w latach 50-60. XX w. Efektem badań były studia opublikowane w „Prace i Materiały Muzeum Archeologicznego w Lodzi”, seria etnograficzna 1961, nr 5: J.P. Dekowski, Ogólna charakterystyka Załęcza Wielkiego, s. 25-36; W. Nowosz, Rolnictwo w Zatęczu Wielkim, s. 37-54; W. Nowosz, A. Lorenz, Chów zwierząt w Załęczu Wielkim, s. 55-62; J. Lech, Zakres wytwórczości rękodzielniczej w Zatęczu Wielkim - rynki zbytu i zakupów, s. 63-74; Z. Neymanowa, Wnętrze chaty w Zatęczu Wielkim, s. 75-95; W. Drozdowska, Grupy rówieśnicze w Załęczu Wielkim, s. 97-117; J.P. Dekowski, Obrzędy i zwyczaje weselne w Załęczu Wielkim, s. 119-133; J. Jastrzębski, Lecznictwo ludowe w Załęczu Wielkim, s. 135-163. Ponadto: W. Drozdowska, Podania z Załęcza Wielkiego, pow. Wieluń, „Łódzkie Studia Etnograficzne” 1962, t. 4, s. 81-86; taż, Istoty demoniczne w Załęczu Wielkim, pow. Wieluń, tamże, s. 117-130. Ostatnio zaś P.J. Kieron, Kilka stów o starych meblach ze wsi Zatęcze Wielkie w regionie wieluńskim, „Rocznik Wieluński” 2018, t. 18, s. 115-125. 
Śląski minister Carl G. von Hoym, zarządzający w tym czasie Prusami Południowymi, otrzymał rozkaz utworzenia na ich obszarze dóbr skarbowych - domen. Wywłaszczonym miano wypłacać tzw. kompetencje w wysokości 50\% dochodu netto z zabranych posiadłości ${ }^{2}$, ich dotychczasowi użytkownicy zaś mieli otrzymać odszkodowania. Deklarację w sprawie tworzenia domen ogłoszono 28 VII 1796 r. $^{3}$ Grupa skonfiskowanych dóbr miała tworzyć urząd domen (Amt) lub intendenturę (Intendanz). Intendentem w Wieluniu mianowano Krausego, który zamieszkał w Kamionce, dawnym ośrodku dóbr kapitulnych (ob. gm. Pątnów). W zestawieniu sporządzonym w 1805 r. (Namentliches Verzeichniss von den Domainen Aemtern) dobra skarbowe w powiecie wieluńskim zgrupowano w trzech urzędach: Kowale, Mierzyce oraz Wieluń z 11 folwarkami i 10 wsiami wydzierżawionymi na lata 1802-1814 Geldnerowi z Kamionki ${ }^{4}$.

Początki szkoły elementarnej w Załęczu Wielkim należy łączyć z działaniami pruskiej administracji, mającymi na celu utworzenie sieci szkół w dobrach domenialnych. Projekty te (pow. wieluński) dotyczyły początkowo: Załęcza Wielkiego i Louisenfeld ${ }^{5}$ (Amt Wieluń), Mierzyc i Krzyworzeki (Amt Kowale) oraz Pątnowa (Amt Mierzyce), w tym ostatnim przypadku pierwotnie brano pod uwagę nieodległy Łaszew. W dalszej perspektywie planowano powstanie szkół w: Kadłubie, Sieńcu i Dzietrznikach. Nie bez znaczenia był fakt, że pierwsze lata panowania Fryderyka Wilhelma III (1797-1840) były okresem korzystnych dla szkolnictwa regulacji prawnych. Nowy minister Julius von Massow, podobnie jak i młody monarcha, zainteresowany był rozwojem kształcenia elementarnego. Prowadzone przez obydwu działania miały na celu zwiększenie liczby szkół i prawne uregulowanie warunków ich funkcjonowania ${ }^{6}$.

Urzędowy spis z roku 1797, sporządzony dla celów poborowych, przynosi informacje, że w Załęczu Wielkim znajdowały się 73 domostwa zamieszkiwane

2 Po odliczeniu od połowy przychodów podatków wszelkich opłat i pozostałych powinności. Uznano, że szacunki przychodów opierać się miały na danych z czasów polskich, I.Ch. Bussenius, Urkunden und Akten zur Geschichte der preußischen Verwaltung in Südund Neuostpreussen 1793-1806, Frankfurt/M/-Bonn 1961, s. 348, „Instruktion für die Kriegs- und Domänenkammern und für die konstituirten Domäneneinrichtungskommisionen wegen Einziehung und Verwaltung der Königlichen und geistlichen Güter", Breslau, 10. September 1796.

3 J. Wąsicki, Ziemie polskie pod zaborem pruskim Prusy Poludniowe 1793-1806. Studium historycznoprawne, Wrocław 1957, s. 224-225.

4 Tajne Pruskie Archiwum Państwowe Berlin-Dahlem, II HA Südpreussen III, sygn. 181, Historisch-statistisches Taschenbuch..., k. 33-45.

5 Kolonia utworzona przez Prusaków ok. 1799 r., na terenie urzędu domen w Wieluniu, między wsiami Grębień, Wierzbie oraz Popowice (współcześnie obszar Józefowa w gm. Pątnów pow. wieluńskim); szerzej: Z. Włodarczyk, Szkoła elementarna w Louisenfeld/Józefów (Urząd Domen w Wieluniu) 1802-1806, [w:] „Rocznik Łódzki” (w druku).

6 D. Łukasiewicz, Szkolnictwo w Prusach Poludniowych (1793-1806) w okresie reform oświeceniowych, Poznań-Warszawa 2004, passim; G. Roellecke, Julius von Massow als „,Kultusminister” (1798-1806). Preußische Bildungspolitik zwischen Wöllner und Humboldt, [w:] Das nachfriederizianische Preußen 1786-1806, red. H. Hattenhauer, G. Landwehr, Kiel 1988, s. 363-381. 
przez 305 osób (150 mężczyzn, 155 kobiet). Wszyscy zaklasyfikowani jako chrześcijanie, choć w tym przypadku nie popełnimy błędu, jeśli uściślimy, że byli to rzymscy katolicy ${ }^{7}$. W 1827 r. naliczono we wsi 48 domostw z 387 mieszkańcami $^{8}$. Warto zadać pytanie, co wpłynęło na tak znaczny spadek liczby zabudowań; niestety w chwili obecnej brak możliwości jednoznacznej odpowiedzi. Pozostają przypuszczenia, że mogło być to skutkiem pożaru, efektem przenosin większości mieszkańców na lewy (bezpieczniejszy) brzeg Warty ${ }^{9}$ lub też działań spisowych, polegających na inkorporowaniu najbliższych, niewielkich skupisk ludzkich. Według danych z $1881 \mathrm{r}$. liczba domostw wzrosła do 59, mieszkańców zaś do 673 - w tym przypadku wiemy, że na całość składały się ponadto: Wilk, Tłumacz, Nosek, Madery, Kubery (Kubary?) i znacznie większe od nich Kluski ${ }^{10}$.

Podobnie jak w przypadku innych tworzonych ówcześnie placówek, administracja podjęła standardowe działania mające na celu zbadanie możliwości finansowych mieszkańców obwodu szkolnego, liczby dzieci w wieku szkolnym (z podziałem na płeć) oraz warunków lokalowych - tak zrobiono choćby w Louisenfeld. W początku 1804 r. budynek szkolny w Załęczu Wielkim został ukończony. Nie posiadamy informacji o jego parametrach. Należy przypuszczać, że był on podobny do powstałego w Louisenfeld, czyli konstrukcja szachulcowa (wypełnienie gliną), w której pod jednym dachem znajdowały się zarówno izba szkolna, jak i mieszkanie nauczyciela ${ }^{11}$.

Sprawą pilną stało się znalezienie odpowiedniego kandydata do pracy z dziećmi: kamera proponowała władzom w Berlinie zatrudnienie Józefa $\mathrm{Ku}$ szewskiego. Przyszły pedagog władał językiem polskim i mówił nieco (etwas) po niemiecku. Nieobca była mu również sztuka pisania i rachowania. Przewidywano,

7 Z. Włodarczyk, Ludność powiatu wieluńskiego w końcu XVIII wieku-spis pruski z 1796 r., „Rocznik Wieluński” 2007, t. 6, s. 77. Nieliczni wyznawcy mozaizmu zamieszkiwali w położonym nieopodal Załęczu Małym - 3 osoby. Pochodzący z 1840 r. wykaz miejscowości wchodzących w skład Parafii Ewangelicko-Augsburskiej w Wieluniu nie wymienia wiernych tej konfesji we wsi [Archiwum Główne Akt Dawnych w Warszawie (dalej: AGAD), Centralne Władze Wyznaniowe Królestwa Polskiego, sygn. 1177, k. 160]. Ewangelików nie wykazuje również spis z lat następnych, tamże, sygn. 1178, k. 33-40.

8 Tabella Miast, Wsi, Osad, Królestwa Polskiego, z wyrażeniem ich położenia i ludności, alfabetycznie ułożona, t. 2, Warszawa 1827, s. 313.

9 J.P. Dekowski uważa, że mogło to nastąpić w związku z uwłaszczeniem (1864); tenże, Ogólna charakterystyka..., s. 23.

10 Spisok naselennym mestnostjam Kališskoj Gubernii, Kalisz 1881, s. 360-361. Dane te powiela Stownik geograficzny Królestwa Polskiego, t. XIV, Warszawa 1895, s. 352.

11 W nieodległym Louisenfeld koszt wystawienia budynku szacowano na $328 \mathrm{rtl} 12 \mathrm{sgr}$. Kamera kaliska proponowała, by środki na tę inwestycję pochodziły z funduszu przeznaczonego na cele oświatowe, samo zaś drewno budowlane z nieodległego rewiru leśnego Załęcze Małe; należy przypuszczać, że podobnie postąpiono w przypadku inwestycji w Załęczu Wielkim. Przykłady podobnych budowli: K.P. Woźniak, Niemieckie osadnictwo wiejskie między Prosna a Pilica $i$ Wista od lat 70. XVIII wieku do 1866 roku. Proces i jego interpretacje, Łódź 2013, s. 209-210. Koszt wystawienia szkoły szacowano na nieco więcej niż połowę rocznej pensji urzędnika średniej rangi (500 rtl); tamże, s. 210. 
że jego uposażenie w gotówce (baar) oscylować będzie około 50 talarów rocznie $^{12}$. Podobnie jak w przypadku innych wiejskich nauczycieli, całość uzupełniała zsypka zbożowa, deputat drewna opałowego oraz określony obszar gruntu rolnego ${ }^{13}$.

W początkach lat 30 . XIX w. obowiązki nauczyciela szkoły elementarnej w Załęczu Wielkim pełnił Baltazar Ruszkiewicz ${ }^{14}$. Jak wynika z korespondencji urzędowej nie posiadał on dostatecznych kwalifikacji do wykonywania zawodu. W grudniu 1834 r. przyznano mu ,pensję emerytalną”, gdyż po wielu latach pracy podupadł na zdrowiu (słaby wzrok). Sam zainteresowany zamierzał w dalszym ciągu pracować - o jego przejściu na emeryturę zadecydował inspektor Marcin Wysznacki z Wielunia.

Sędziwy Ruszkiewicz liczył lat $70(1834)^{15} \mathrm{i}$ - jak pisał - był „na siłach fizycznych osłabiony". Władze przyznały mu 150 zł emerytury rocznie. Kwota niewielka, zważywszy że pedagog miał na utrzymaniu owdowiałą córkę z dwojgiem małoletnich dzieci. Nie dość na tym, razem z ojcem zamieszkiwał również syn Napoleon - kaleka, który nie był w stanie sam się utrzymać. To właśnie w nim Ruszkiewicz upatrywał swego pomocnika, ale w czasie starań ojca o pozwolenie na dalsze wykonywanie zawodu Napoleon zmar1 ${ }^{16}$.

W tym czasie budynek szkoły był w ,najgorszym stanie”. Władze oświatowe Królestwa Polskiego - Komisja Rządowa Spraw Wewnętrznych, Duchownych i Oświecenia Publicznego (KRSWDiOP) - zobligowały Komisję Województwa Kaliskiego do zajęcia się sprawą remontu. Jednocześnie postulowano powiększenie pensji nauczyciela - również i w tym przypadku władze wojewódzkie miały wskazać źródła finansowania ${ }^{17}$.

12 AGAD, Generalne Dyrektorium Prusy Południowe VII, sygn. 672, Acta betr. Einrichtung der Schulen in dem Domainen Amte Wielun 1802-1806, bp. Kamera do władz w Berlinie, Kalisz 27 III 1804, odpowiedź: Berlin 12 V 1804.

13 D. Łukasiewicz, Szkolnictwo w Prusach Poludniowych..., s. 112. Nowym rozwiązaniem było rozłożenie podatku szkolnego (Schulgeld) na wszystkich mieszkańców obwodu szkolnego, wielkość składki uzależniona była od zamożności poszczególnych płatników; szerzej tamże, s. 102-103.

$14 \mathrm{Z}$ aktu zgonu wynika, że urodził się w Wieluniu w pocz. lat 60 . XVIII w., zmarł 12 XII 1844 w Załęczu Wielkim (,wdowiec, były nauczyciel”), Archiwum Państwowe w Łodzi (dalej: APŁ), Akta stanu cywilnego Parafii Rzymskokatolickiej w Dzietrznikach, sygn. 1844, Zgony, akt nr 43 (tu imię zmarłego Balcer). W dokumentach władz oświatowych występuje jako Baltazar, APŁ, Dyrektor Gimnazjum w Piotrkowie (dalej: DGP), sygn. 209, s. 2 i in. W spisie z 1791 znajdujemy w Wieluniu (ul. Różana) Wojciecha Ruszkiewicza (H. Żerek-Kleszcz, Przyjęcia do prawa miejskiego w Wieluniu, „Rocznik Wieluński” 2008, t. 8, s. 75), brak informacji o związkach z Baltazarem.

15 Wynika $\mathrm{z}$ tego, że urodził się około 1764 r., natomiast $\mathrm{z}$ aktu zgonu wynika, że przyszedł na świat około roku 1761. Czy w związku ze staraniami o dalsze wykonywanie zawodu, korzystając z braku wiarygodnych dokumentów, zaniżył swój wiek?

16 Napoleon Ruszkiewicz, ur. ok. 1812, zm. 16 I 1836, APŁ, Akta stanu cywilnego Parafii Rzymskokatolickiej w Dzietrznikach, sygn. 1836, Zgony, akt nr 5.

17 APŁ, DGP, sygn. 209, s. 2. Pismo KRSWDiOP z 18/30 VI 1835. 
Budżet placówki na lata 1834-1839 przewidywał 274 zł 12 gr zarówno po stronie przychodów, jak i wydatków. Pieniądze i naturalia pochodzily ze zbiórki od mieszkańców wsi. Większa część wspomnianej kwoty przeznaczona była na uposażenie nauczyciela. Ponadto zbierano dla niego 15 wierteli żyta, 4 tatarki, 2 pszenicy, 3 jęczmienia, 1 prosa, 2 grochu. Do opalania izby szkolnej służyło 10 sążni „drzewa jako deputat”"18.

Sprawą obsady placówki w Załęczu Wielkim zajmował się jej bezpośredni zwierzchnik Inspektor Szkoły Obwodowej Wieluńskiej - Marcin Wysznacki. Poinformował on dyrektora gimnazjum w Piotrkowie, do którego należał nadzór nad oświatą na terenie województwa kaliskiego, o wakującym etacie. Ruszkiewicz, de facto emeryt, uczył w dalszym ciągu i domagał się „nadpłaty” za wykonywaną pracę oraz proponował, że przyjmie pomocnika („własnym kosztem”). Powoływał się na fakt, że egzamin przeprowadzony w końcu roku szkolnego wypadł pomyślnie (1834) - „nie na próżno młodzież do szkoły pod moim przewodnictwem będącej uczęszczała”. Inspektor zapytywał zwierzchnika, czy możliwe jest otrzymywanie pensji i zarazem pobieranie emerytury. Ponadto informował, że chęć podjęcia pracy w Załęczu Wielkim „objawił” Andrzej Podgórski (Podgurski), którego kwalifikacje zostały potwierdzone egzaminem w szkole obwodowej. Kandydat złożył równocześnie „świadectwo nie należenia do rewolucji” [powstanie listopadowe - przyp. Z.W.], świadectwo z „wykonanej” przysięgi na wierność panującemu i jego następcy, deklarację o nieuczestniczeniu w tajnych organizacjach oraz pisemne potwierdzenie, że pracował jako pomocnik nauczyciela przy swoim ojcu ${ }^{19}$. Dla nowego pedagoga przewidziano stanowisko „zastępcy nauczyciela", będące odpowiednikiem okresu próbnego. Starania Podgórskiego kończy nominacja KRSWDiOP wydana dnia 11 I $1836 \mathrm{r}^{20}$

Jak wynika z raportu o stanie szkoły z 1837 r. uczęszczało do niej 74 dzieci (37 dziewczynek, 37 chłopców), w tym 4 ,stanu miejskiego”. W trakcie roku szkolnego jedno dziecko zmarło. Jednocześnie stwierdzono, że w obwodzie szkolnym zamieszkiwało 17 dzieci, które „żadnych nauk nie pobierały”. Uczniowie podzieleni zostali na trzy oddziały. Pierwszy, stanowili najbardziej zaawansowani, którzy posiedli sztukę czytania, pisania i rachowania (zasadniczy program nauczania); zaliczono do niego 12 dzieci, w tym 10 chłopców. W drugim (,składano sylaby”) na 13 uczniów było 12 dziewczynek. Wreszcie w trzecim, początkowym (,litery poznających”) kształciła się większość uczniów - 49. Na szczególną pochwałę, że względu na osiągnięte wyniki, zasługiwało 5 dzieci. Dodatkowo uczniowie „ćwiczyli się w robotach rolniczych”, choć nie wyjaśniono na czym one polegały. Naukę prowadzono „na godziny”, co w praktyce znaczyło powtarzanie poszczególnych fragmentów, a następnie ,przesłuchiwanie”. Nauczyciel Podgórski określony został jako „zdatny”.

W dalszym ciągu niepokój budził stan budynku szkolnego; należy więc mniemać, że nic nie uczyniono w sprawie jego remontu. Stanowił on własność

\footnotetext{
18 Tamże, s. 5.

19 Tamże, s. 3-15.

20 Tamże, s. 22.
} 
rządową (spuścizna po rządach pruskich?), lecz „ulewa i mrozy rozpędzają dzieci i nauczyciela ze szkoły". Całości obrazu dopełniały braki w wyposażeniu, dotyczyło to zarówno mebli, jak i pomocy naukowych, które stanowiły raptem dwie książki ${ }^{21}$. Nowy obiekt powstał w $1841 \mathrm{r}$. Prac podjął się Mikołaj Załęcki (karczmarz); nie obyło się jednak bez zarzutów odnośnie do jakości wykonanej pracy ${ }^{22}$.

Kilka lat później - w 1843 r. - do szkoły uczęszczało tylko 46 uczniów (w tym 2 stanu szlacheckiego, 1 mieszczańskiego). Jednocześnie wzrosła liczba dzieci zamieszkałych na terenie „okręgu szkoły” nie objętych nauczaniem - było ich aż 54. Wspomniany okręg tworzyły wsie „Załęcze Wielkie i Załęcze Małe z przyległościami” $(1844)^{23}$. Nieco więcej - 50 uczniów kształciło się w roku szkolnym 1852/185324.

Czy spadek liczby uczniów spowodowany był radykalnymi zmianami w programie nauczania? Został on bowiem poszerzony o język rosyjski, historię, naukę moralną oraz śpiewy kościelne w języku polskim. Powiększeniu uległy zbiory naukowe -5 książek, w tym 2 do nauki języka rosyjskiego; notowano jednak braki w wyposażeniu w sprzęt. Nauka odbywała się w nowym budynku, określonym jako „wygodny”, choć „potrzebujący wyrzucenia ścian wewnętrznych wapnem lub gliną"25.

Opiekun szkoły, ks. Michał Guzdzielski (komendarz dzietrznicki) poświęcił nieco uwagi postępom uczniów. O ile jeszcze w 1844 r. pisał, że Podgórski „udziela nauk z korzyścią” oraz pozytywnie opiniował jego prowadzenie (,sprawuje się moralne"), o tyle w roku 1846 zwracał uwagę na mizerne wyniki egzaminu (w szkole pracował Hennig). Przyczyn tego stanu upatrywał w nieregularnym uczęszczaniu dzieci do szkoły, co było spowodowane wylewami Warty. Osiągnięte przez uczniów w roku następnym wyniki również nie zadowoliły duchownego. Ostrze krytyki skierował w stronę rodziców, którym zarzucał brak troski „o oświecenie swych dzieci”. Jego uwagę zwrócił także spadek liczby uczniów, dlatego postulował użycie przymusu wobec rodziców ignorujących obowiązek szkolny ${ }^{26}$.

W 1837 r. zasób biblioteczny stanowiły dwie książki, a w roku szkolnym 1846/1847 zbiór wzrósł do 13 pozycji. Część z nich to podręczniki do nauki ję-

21 Tamże, s. 28-29. Raport został sporządzony 14/26 lipca 1837 przez „Opiekuna Szkoły Załęcza Wielkiego".

22 Nauczyciel Podgórski odpowiadając na ,zarzuty w sprawie zaboru funduszy szkolnych, pisał m.in.: „Tenże Mikołaj Załęcki w roku 1841 wystawił nowy dom szkolny kosztem skarbu i stowarzyszonych bez należnego wybielenia ścian wewnętrznych i dobrego przybicia podłogi itp.”, tamże, s. 129-130. Wśród zarzutów wobec wykonawcy znajdujemy i taki: „Nie trzy, lecz tylko dwie szyby nowe wprawił w okna szkolne Załęcki”, tamże, s. 131.

Tamże, s. 116

Tamże, s. 192.

Tamże, s. 47. Raport sporządzony $1 / 13$ czerwca 1843.

Tamże, s. 54, 83, 86. 
zyka rosyjskiego, w które szczególnie intensywnie zaopatrywano szkoły elementarne. Nauczanie religii wspierano wielce popularnym ówcześnie thumaczeniem książki ks. Jana E. Schmidta pt. Msza święta w swoich Obrzędach.... Posiadano również egzemplarz książki Tymoteusza Rodziszewskiego pt. Bajki i powiastki dla dzieci (I wyd. 1843). Pomocą w nauczaniu matematyki służył Popularny wykład poczatków arytmetyki autorstwa A. Barcińskiego ${ }^{27}$. Jak widać nie był to zasób szczególnie bogaty, nie wiemy również w jakim stopniu był wykorzystywany.

Podgórski pracował w Załęczu Wielkim do początków 1845 r., następnie przeszedł do Wiewca (pow. piotrkowski). Zabrał ze sobą fundusz remontowy szkoły (15 rubli 12 kop.) ${ }^{28}$. Władze oświatowe nakazały opiekunowi szkoły w Wiewcu, by ściągnął ową kwotę z poborów pedagoga. Sprawa nie była jednak prosta. Nauczyciel wykazał się wyjątkową wytrwałością, jeśli chodzi o odzyskanie należnych mu środków. $\mathrm{W}$ wyjaśnieniu problemów związanych $\mathrm{z}$ administrowaniem funduszami szkolnymi nie pomaga fakt, że po śmierci ks. Kowalskiego (opiekuna szkoły), to właśnie Podgórski zajmował się poborem składki (18421844). Efektem jego działań jest zestawienie zalegających z płatnością („Dezygnacja [sic!] debetentów tych, którzy etatem naznaczonej należności szkolnej nauczycielowi we wsi Załęczu Wielkiem po dzień 15 lutego 1845 r. nie oddali"29). Władze oświatowe nakazały ks. Guzdzielskiemu przyjazd do Załęcza i zbadanie zarzutów Podgórskiego. W efekcie jego działań powstał protokół z 27 X/8 XI 1845 r., w którym „debetenci” ustosunkowali się do zarzutów poprzedniego nauczyciela $^{30}$. Badanie „delegata” wykazało, że relacje między mieszkańcami wsi a nauczycielem były mocno skomplikowane. Na jaw wyszło wiele drobnych zobowiązań finansowych, którymi był obarczony. Na zebraniu pojawił się także Jan Sztuka z Załęcza Wielkiego. Tą drogą dochodził 1 rubla 20 kop., które pożyczył Podgórski, na co przedstawił świadków (nauczyciel Hennig i sołtys Załęcza Małego Wojciech Sobel) ${ }^{31}$. W odpowiedzi Podgórski sporządził wielostronicowy elaborat (16/18 II 1846), w którym szczegółowo objaśniał stosunki materialne między nim a poszczególnymi „,debetentami”" ${ }^{2}$.

We wrześniu 1844 r. starania o posadę nauczyciela w Załęczu Wielkim podjął Karol Hennig (zam. w Działoszynie). Jego działania odniosły pozytywny skutek - rozpoczął pracę 3/15 lutego $1845 \mathrm{r}$. W dalszym ciągu podejmowano kroki mające na celu wzrost uposażenia, które zostało zmniejszone (budżet 1845 r.). Starania $\mathrm{w}$ tym kierunku czynili zarówno opiekun szkoły, jak i inspektor Wysznacki. Ten ostatni w jednym z pism do dyrektora Gimnazjum w Piotrkowie

27 Tamże, s. 86.

28 W rzeczywistości były to pieniądze przeznaczone na nagrody dla dzieci (3 ruble), materiały piśmienne ( 3 ruble) oraz "na potrzeby nadzwyczajne do dyspozycji rządu gubernialnego" - 9 rubli 12 kop., tamże, s. 105 (Raport o niewłaściwym zaborze pieniężnego remanentu szkoły Załęcze Wielkie przez b. nauczyciela tejże szkoły Podgórskiego 4/16 czerwca 1845).

29 Tamże, s. 111-112.

30 Tamże, s. 139-153.

31 Tamże, s. 152.

32 Tamże, s. 123-137. 
przypominał, że uposażenie stróża szkoły powiatowej w Wieluniu to 45 rubli, nauczyciela zaś (ukończone 4 klasy szkoły powiatowej) - 64 ruble 14 kop. ${ }^{33}$ Dyrektor Gimnazjum w Piotrkowie poprosił swoich zwierzchników (Zarząd Okręgu Naukowego Warszawskiego) o wypłacanie pensji w dawnej wysokości. Władze oświatowe niezwłocznie przekazały sprawę do rozpatrzenia Rządowi Gubernialnemu Warszawskiemu. Ten jednak odrzucił wniosek, thumacząc, że rezerwa pozostawiona $\mathrm{w}$ dyspozycji jest wykorzystywana na zakup książek, konieczne remonty, utrzymanie czystości. Zwracano uwagę, że w razie niedoboru składek szkoła nie posiada żadnych zapasów na pokrycie roszczeń nauczyciela ${ }^{34}$.

Sam Hennig również nie pozostawał bezczynny, zwłaszcza że niedobory w kasie, spowodowane zagarnięciem przez jego poprzednika, ograniczały możliwości remontu placówki. Główną bolączką było niedostateczne ogrzewanie izby lekcyjnej, które miało wpływ na poziom nauczania, bo dzieci: „, przyczyny przemagającego zimna przymuszone były pamiętać o rozgrzewaniu siebie i chronić się od odmrożenia nóg i rąk”, a i same piece „przez czas i silne palenie bardzo są porozstąpiane i zdezelowane". Opis szkoły nie nastrajał pozytywnie. Zdaniem pedagoga ściany były zbyt cienkie - spomiędzy 5-calowych drewnianych bali powypadała glina, którą wypełnione były szczeliny ${ }^{35}$. Budżet na $1845 \mathrm{r}$. zamykał się w kwocie 75 rubli 24 kop., zarówno po stronie wydatków, jak i przychodów. Podstawę tych ostatnich stanowiła składka pieniężna -43 ruble 56 kop. oraz naturalia (żyto, owies, jęczmień i kartofle), których wartość oceniono na 31 rubli 68 kop. Większość tej kwoty otrzymywał nauczyciel (gotowizna plus naturalia) - 60 rubli. Tym samym pozycja ,inne wydatki” obejmowała niewiele -6 rubli 60 kop. (materiały piśmienne, nagrody dla najlepszych uczniów, wyrąb drzewa opałowego, uprawa ogrodu). Reszta pozostawała do dyspozycji rządu gubernialnego z przeznaczeniem na ,nieprzewidziane wydatki (8 rubli 64 kop. $)^{36}$.

Na lata 1854-1859 przewidywano, że coroczne przychody szkoły zamkną się kwotą 77 rubli 56 kop. ze składek mieszkańców: w gotowiźnie - 43 ruble 56 kop. oraz naturaliach (żyto, pszenica, jęczmień, owies, groch, kartofle), których wartość oszacowano na 34 ruble. Po stronie wydatków dominowała płaca nauczyciela - 63 ruble, z czego 29 stanowiła gotówka. Stróż pobierał 4, natomiast kominiarzowi płacono 1 rubla rocznie. Pozostałe 9 rubli 55 kop. wydatkowano na materiały piśmienne $(1,50)$, wyrąb drewna opałowego $(2,40)$, uprawę ogrodu $(2)$. Reszta, czyli 3 ruble 66 kop., pozostawały w gestii rządu gubernialnego ${ }^{37}$.

Ostatnie lata istnienia szkoły w Załęczu charakteryzują się częstymi zmianami na stanowisku nauczyciela, a co za tym idzie przerwami w nauce. Pracujący

33 Tamże, s. 63-64. Etat szkoły zmniejszono o 4 ruble 14 kop., Wysznacki proponował powrót do poprzednich wartości, motywując to m.in. tym, że tamtejsi włościanie „nie są tak biedni”; tamże, s. 65.

34 Tamże, s. 76. Pismo Dyrektora z listopada 1845, odpowiedź władz oświatowych z 8/20 maja 1846; tamże, s. 77-78.

35 Tamże, s. 109-110.

36 Tamże, s. 71-73. Etat na lata 1845-1847 zatwierdzony w Warszawie 7 maja 1845.

37 Tamże, s. 187-189. 
tutaj od 1845 r. Hennig nie zyskał zaufania zarówno mieszkańców wsi (,stowarzyszonych"), jak i opiekuna. Pierwsi pisali skargi na postępowanie nauczyciela, drugi udzielał nagan. To wszystko spowodowało reakcję władz oświatowych - pedagog został karnie przeniesiony do placówki w kolonii Ksawerów (w pow. sieradzkim). Na jego miejsce nadzorca etatowy szkoły proponował Konrada Tanierskiego. Jednak jego zwierzchnicy na stanowisku tym widzieli Jana Chrempińskiego ${ }^{38}$, który wykształcenie zdobył w Szkole Powiatowej w Wieluniu (świadectwo z 15/27 VI 1846). Chcąc uzyskać atut w staraniach o posadę w $1847 \mathrm{r}$. zdał egzamin przeprowadzony w Gimnazjum Gubernialnym w Warszawie ${ }^{39}$. Jednak już w kwietniu 1854 r. Chrempiński wystąpił do władz oświatowych z prośbą o przeniesienie do Kurowa (w pobliżu Wielunia), gdzie zmarł nauczyciel Narcyz Leszczyński. Po trzech latach nienagannej pracy pragnął poprawić swoje warunki materialne (,nędzne i szczupłe utrzymanie moje w Załęczu”). Należy przypuszczać, że główną przyczyną była znacznie mniejsza odległość z Kurowa do rodzinnej Praszki.

Już w sierpniu 1854 r. na miejsce Chrempińskiego wyznaczono Aleksandra Stadlera - stypendystę Instytutu Nauczycieli Elementarnych w Radzyminie, który pracę w Załęczu Wielkim rozpoczął 11/23 IX 1854 r. Po kilku miesiącach opuścił on stanowisko i wyjechał (,na kurację"). Stadler przedstawiał świadectwa lekarskie, że choroba oczu uniemożliwia mu czytanie i pisanie. W celu kuracji udał się do rodziców w Zduńskiej Woli oraz brata - II nauczyciela szkoły rzemieślniczo-niedzielnej w tymże mieście. Władze oświatowe nakazały Stadlerowi powrót do Załęcza oraz poddanie się badaniom lekarzy urzędowych. Zupełnie inne świadectwo na całą sprawę rzuca pismo Grzegorza Gruszczyńskiego, nauczyciela we wspomnianej szkole rzemieślniczej, skonfliktowanego z bratem Aleksandra - Adolfem. Gruszczyński podaje w wątpliwość chorobę Stadlera („Aleksander Stadler nigdy nie był chorym i nie jest, to całe miasto zaświadczyć może" ${ }^{40}$. Dodatkowe zadziwienie wywołuje fakt, że bracia Stadlerowie wystąpili do władz

38 Chrempiński (Chrępiński) Jan, ur. ok. 1828 w Praszce. Żona Agnieszka z Kabotów (zm. 1908), z tego związku m.in. synowie: Stanisław, Julian i Józef wszyscy urodzeni w Kurowie, J. Grajnert, Wspomnienia ze szkół wieluńskich podane przez byłego ich ucznia, opr., wstęp S.T. Olejnik, Wieluń 2008, s. 46; APŁ, Akta stanu cywilnego Parafii Rzymskokatolickiej w Praszce, sygn. 1866 (Urodzenia), akt nr 40; DGP, sygn. 398, b.p. Warto wspomnieć, że w $1861 \mathrm{r}$. znalazł się w gronie kilku pedagogów podanych przez nadzorcę etatowego szkół powiatu wieluńskiego Mikołaja Pancerama do nagrody (,za gorliwe wykonywanie obowiązków i moralne prowadzenie"), zob. Z. Włodarczyk, Chrempiński (Chrępiński) Jan, [w:] Wieluński słownik biograficzny, t. 3, red. Z. Szczerbik, Z. Włodarczyk, s. 30.

39 APŁ, DGP, sygn. 209, s. 173. Egzamin obejmował wiedzę kandydata na nauczyciela z religii (celująco), j. polskiego i j. rosyjskiego, arytmetyki i pedagogiki (w stopniu dobrym).

40 Paradoksalnie niedługo potem (28 III 1859) zmarł Adolf Stadler, który przeszedł do pracy jako pisarz wójta gm. Zduńska Wola, APŁ, Akta stanu cywilnego Parafii Rzymskokatolickiej Zduńskiej Woli, sygn. 1859 (Zgony), akt nr 34. Natomiast młodszy o dwa lata Aleksander dożył sędziwego wieku - zmarł w 1911 w Kutnie, APŁ, Akta stanu cywilnego Parafii Rzymskokatolickiej w Kutnie, sygn. 1911 (Zgony), akt nr 66. 
oświatowych o zamianę - dotychczasowy nauczyciel z Załęcza chciał pozostać w Zduńskiej Woli przy rodzicach. Plany rodzeństwa nie uzyskały jednak akceptacji władz ${ }^{41}$.

Nowym i zarazem ostatnim - jak pokazała przyszłość - nauczycielem w Załęczu Wielkim był Aleksander Szkalmierski. Młody pedagog ukończył w $1847 \mathrm{r}$. sieradzką szkołę powiatową i po uzyskaniu aprobaty rady Gimnazjum w Piotrkowie (1855), rozpoczął pracę w Chróścinie (ob. pow. wieruszowski), skąd przeszedł do Załęcza. Przeprowadzka wiązała się ze znacznym wzrostem rocznego uposażenia - z 40 rubli na 75 . W początkach $1859 \mathrm{r}$. władze oświatowe podjęły decyzję „o zwinięciu szkoły elementarnej we wsi Załęcze Wielkie”. Sytuacja Szkalmierskiego była nie do pozazdroszczenia. Miał na utrzymaniu żonę i czwórkę dzieci. Mając informację, że szkoła zostanie zamknięta, „stowarzyszeni” nie płacili składek; nauczyciel zaś, który nie otrzymał formalnych dokumentów o likwidacji, w dalszym ciągu wykonywał swe obowiązki ${ }^{42}$.

Nie podano powodów, którymi kierował się kurator, wydając rządowi gubernialnemu polecenie likwidacji szkoły i zwolnienia nauczyciela („licząc takowe uwolnienie od dnia wprowadzenia w wykonanie decyzji zwijającej szkołę powyższą" ${ }^{43}$. Trudności z obsadą, częste zmiany pedagogów, problemy z egzekwowaniem składki należały z pewnością do zasadniczych. W początkach lat 70. XIX w. rozpoczęły pracę placówki w pobliskich wsiach: Pątnowie i Dzietrznikach, nieco później w Popowicach. Na nową szkołę mieszkańcy Załęcza Wielkiego musieli poczekać ponad pół wieku - powołały ją władze okupacyjne podczas I wojny światowej ${ }^{44}$.

\section{Summary}

\section{Elementary School in Zalęcze Wielkie (Wieluń District) 1804-1859}

The village of Załęcze Wielkie, located in the south-eastern part of the Wielun district, was one of the villages of Kamionkowo dominium, which belonged to the chapter of the Gniezno archbishopric. As a result of the Second Partition of Poland, these areas came under the rule of the Hohenzollerns (1793), in the so-called South Prussia (Südpreussen). After the Kościuszko Uprising (1794), it was decided to confiscate them and create domains. The beginnings of

41 APŁ, DGP, sygn. 209, s. 216-223.

42 Tamże, s. 284-285.

43 Tamże, s. 285. Wypis z protokołu posiedzenia Rady Wychowania Publicznego z dnia 17/29 sierpnia $1859 \mathrm{r}$.

44 Według danych z 1886 r. na terenie obecnej gminy Pątnów działały tylko szkoły w Dzietrznikach i Pątnowie, zob. wykaz placówek oświatowych sporządzony na potrzeby administracji wyższego szczebla w poszczególnych powiatach guberni kaliskiej (stan 1 I 18861 I 1887 - starego stylu) APŁ, zespół Kancelaria Gubernatora Kaliskiego, sygn. 344, s. 44 58 (materiały z terenu powiatu wieluńskiego). Z czasem powstała szkoła w Popowicach (Pamjatnaja Knižka Kališskoj Gubernii na 1904, Kalisz 1904, s. 248, brak nauczyciela). 
elementary school in Załęcze Wielkie should be linked with the activities of the Prussian administration aimed at creating a network of schools in newly gained areas. The school probably started its activity in 1804 - when the school building was put into use. Throughout its existence, the facility struggled with material difficulties. The contribution of the village inhabitants was barely enough for the teacher's salary. There was a lack of funds for proper maintenance of the school building. Hence the staffing trouble: teachers, especially in the last period of the school's existence, changed very often. The facility existed until 1859 , when it was closed by the decision of the educational authorities of the Kingdom of Poland.

Keywords: Załącze Wielkie, Wieluń, school, education, Poland, XIX century, South Prussia, Kingdom of Poland

\section{Bibliografia}

\section{Archiwalia}

Archiwum Główne Akt Dawnych w Warszawie

Centralne Władze Wyznaniowe Królestwa Polskiego, sygn. 1177.

Generalne Dyrektorium Prus Południowych VII, sygn. 672.

Archiwum Państwowe w Łodzi

Akta stanu cywilnego Parafii Rzymskokatolickiej w Dzietrznikach, sygn. 1836, 1844.

Akta stanu cywilnego Parafii Rzymskokatolickiej w Kutnie, sygn. 1911.

Akta stanu cywilnego Parafii Rzymskokatolickiej w Praszce, sygn. 1866.

Akta stanu cywilnego Parafii Rzymskokatolickiej Zduńskiej Woli, sygn. 1859.

Dyrektor Gimnazjum w Piotrkowie, sygn. 209, 398.

Generalne Dyrektorium Prus Południowych III, sygn. 181.

Kancelaria Gubernatora Kaliskiego, sygn. 344.

Tajne Pruskie Archiwum Państwowe Berlin-Dahlem

Źródła drukowane

Bussenius I.Ch., Urkunden und Akten zur Geschichte der preußischen Verwaltung in Süd- und Neuostpreussen 1793-1806, Frankfurt/M/-Bonn 1961.

Grajnert J., Wspomnienia ze szkót wieluńskich podane przez byłego ich ucznia, opr., wstęp S.T. Olejnik, Wieluń 2008.

Pamjatnaja Knižka Kališskoj Gubernii na 1904, Kalisz 1904.

Stownik geograficzny Królestwa Polskiego i innych krajów słowiańskich, red. B. Chlebowski, W. Walewski, F. Sulimierski, t. XIV, Warszawa 1895.

Spisok naselennym mestnostjam Kališskoj Gubernii, Kalisz 1881.

Tabella Miast, Wsi, Osad, Królestwa Polskiego, z wyrażeniem ich położenia i ludności, alfabetycznie ułożona, t. 2, Warszawa 1827.

\section{Opracowania}

Dekowski J.P., Obrzędy i zwyczaje weselne w Załęczu Wielkim, „Prace i Materiały Muzeum Archeologicznego w Łodzi”, seria etnograficzna 1961, nr 5, s. 119-133.

Dekowski J.P., Ogólna charakterystyka Załęcza Wielkiego, „Prace i Materiały Muzeum Archeologicznego w Łodzi”, seria etnograficzna 1961, nr 5, s. 25-36.

Drozdowska W., Grupy rówieśnicze w Załęczu Wielkim, „Prace i Materiały Muzeum Archeologicznego w Łodzi”, seria etnograficzna 1961, nr 5, s. 97-117. 
Drozdowska W., Istoty demoniczne w Zatęczu Wielkim, pow. Wieluń, „,Lódzkie Studia Etnograficzne" 1962, t. 4, s. 117-130.

Drozdowska W., Podania z Załęcza Wielkiego, pow. Wieluń, „,Lódzkie Studia Etnograficzne” 1962, t. 4, s. 81-86.

Jastrzębski J., Lecznictwo ludowe w Załęczu Wielkim, „Prace i Materiały Muzeum Archeologicznego w Łodzi", seria etnograficzna 1961, nr 5, s. 135-163.

Kieroń P.J., Kilka słów o starych meblach ze wsi Załęcze Wielkie w regionie wieluńskim, „Rocznik Wieluński” 2018, t. 18, s. 115-125.

Lech J., Zakres wytwórczości rękodzielniczej w Załęczu Wielkim - rynki zbytu i zakupów, „Prace i Materiały Muzeum Archeologicznego w Łodzi”, seria etnograficzna 1961, nr 5, s. 63-74.

Łukaszewicz D., Szkolnictwo w Prusach Poludniowych (1793-1806) w okresie reform oświeceniowych, Poznań-Warszawa 2004.

Neymanowa Z., Wnętrze chaty w Załęczu Wielkim, „Prace i Materiały Muzeum Archeologicznego w Łodzi”, seria etnograficzna 1961, nr 5, s. 75-95.

Nowosz W., Rolnictwo w Załęczu Wielkim, „Prace i Materiały Muzeum Archeologicznego w Łodzi”, seria etnograficzna 1961, nr 5, s. 37-54.

Nowosz W., Lorenz A., Chów zwierząt w Załęczu Wielkim, „Prace i Materiały Muzeum Archeologicznego w Łodzi”, seria etnograficzna 1961, nr 5, s. 55-62.

Roellecke G., Julius von Massow als „,Kultusminister” (1798-1806). Preußische Bildungspolitik zwischen Wöllner und Humboldt, [w:] Das nachfriederizianische Preußen 1786-1806, red. H. Hattenhauer, G. Landwehr, Kiel 1988.

Szczygielski W., Produkcja rolnicza gospodarstwa folwarcznego w Wieluńskiem od XVI do XVIII wieku, Łódź 1963.

Topolski J., Gospodarstwo wiejskie w dobrach arcybiskupstwa gnieźnieńskiego od XVI do XVIII wieku, Poznań 1958.

Topolski J., Położenie i walka klasowa chłopów w XVIII w. w dobrach arcybiskupstwa gnieźnieńskiego, Poznań 1956.

Topolski J., Rozwój latyfundium arcybiskupstwa gnieźnieńskiego od XVI do XVIII wieku, Poznań 1955.

Wąsicki J., Ziemie polskie pod zaborem pruskim Prusy Południowe 1793-1806. Studium historycznoprawne, Wrocław 1957.

Włodarczyk Z., Chrempiński (Chrępiński) Jan, [w:] Wieluński słownik biograficzny, t. 3, red. Z. Szczerbik, Z. Włodarczyk, s. 30.

Włodarczyk Z., Ludność powiatu wieluńskiego w końcu XVIII wieku - spis pruski z 1796 r., „Rocznik Wieluński” 2007, t. 6, s. 71-80.

Woźniak K.P., Niemieckie osadnictwo wiejskie między Prosna a Pilica i Wisła od lat 70. XVIII wieku do 1866 roku. Proces i jego interpretacje, Łódź 2013.

Żerek-Kleszcz H., Przyjęcia do prawa miejskiego w Wieluniu, „Rocznik Wieluński” 2008, t. 8, s. 51-76. 